IRA-International Journal of Management \& Social Sciences

ISSN 2455-2267; Vol.07, Issue 02 (2017)

Pg. no. 258-269

Institute of Research Advances

http://research-advances.org/index.php/RAJMSS

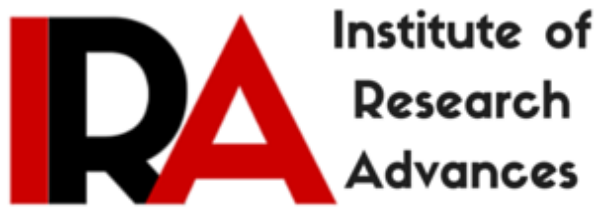

\title{
Entrepreneurship and Self-Sustainability in Nigeria
}

Dr. Timothy T. Alabar

Benue State University, Makurdi- Nigeria.

Mtswenem Paul Shima

Benue State Board of Internal Revenue, Makurdi- Nigeria.

Type of Review: Peer Reviewed.

DOI: http://dx.doi.org/10.21013/jmss.v7.n2.p16

\section{How to cite this paper:}

Alabar, T., \& Shima, M. (2017). Entrepreneurship and Self-Sustainability in Nigeria. IRAInternational Journal of Management \& Social Sciences (ISSN 2455-2267), 7(2), 258-269. doi:http://dx.doi.org/10.21013/jmss.v7.n2.p16

(C) Institute of Research Advances

\section{(cc) EY-NC}

This work is licensed under a Creative Commons Attribution-Non Commercial 4.0 International License subject to proper citation to the publication source of the work.

Disclaimer: The scholarly papers as reviewed and published by the Institute of Research Advances (IRA) are the views and opinions of their respective authors and are not the views or opinions of the IRA. The IRA disclaims of any harm or loss caused due to the published content to any party. 


\section{ABSTRACT}

The need for this study arose from the worrisome state of unemployment in the country and the obvious neglect of the direct effect of entrepreneurship to entrepreneurs. The study therefore, attempts to ascertain the possible relationship between entrepreneurship and self sustainability in Nigeria. The study adopted a survey design and the six Geo-political zones of the country; south-east, south-south, south-west, north central, north east and north west constituted the population for the study from which a purposive sample of ten (10) entrepreneurs from each zone was taken with particular reference to those that have survived the five (5) years of existence and the total was 60. Data so collected was presented in tabular form and analyzed. The Friedman's Chi-square was instrumental in the test of the hypothesis formulated and the result showed a significant positive relationship between entrepreneurship and self-sustainability in Nigeria. The study therefore, recommended that considering the pivotal role that entrepreneurship plays in enhancing self-sustainability in the economy, all hands must be on desk to encourage and support entrepreneurial activities in order to curb the high level menace of unemployment rate as well as provide a supporting ground for economic sustainability of the country.
\end{abstract}

Keywords: Entrepreneurship, Self-sustainability, Nigeria.

\title{
INTRODUCTION
}

Governments at various levels in Africa and Nigeria in particular have seemingly failed in providing gainful employment for her teeming populace. Although, Nigeria as a country has numerous business and investment potentials due to the abundant, vibrant and dynamic human and natural resources it possesses. Tapping these resources require the ability to identify potentially useful and economically viable fields of endeavors. These human and natural resources notwithstanding, Nigeria is still one of the poorest countries in the world and has one of the highest rates of youth unemployment in subSahara Africa.

Many other countries have been able to energize and transform entrepreneurship sub-sector to such a vibrant one that they have been able to reduce to the barest minimum their unemployment and poverty level because of the immense contribution of the sub-sector to their economic growth and development, but such cannot be said of Nigeria. In respect of the above sad and deplorable situation, the government has done little to reduce the misery and frustrations of the citizenry. This has foisted a state of hopelessness on majority of young people who have resorted to any means including crime to succeed in life. They resort to vices because they are not gainfully engaged. In other words, they are unemployed; not because they lack the qualification but because the system has been crippled politically, economically, socio-culturally and even religiously.

People especially youths and graduates became displaced economically (Kuratko, 2009), a situation that clearly negates the Millennium Development Goals for 2015, I and II: to halve the proportion of people living in extreme poverty and to halve the proportion of people suffering from hunger respectively. This is the obvious reason why so much emphasis have been shifted to entrepreneurship since it has become apparent that government alone cannot cater for the employment needs of her citizenry. To this effect, the government of Nigeria has embarked on numerous programs and policies such as YOU-WIN, establishment of entrepreneurship centres in the six geo-political zones in the country, SMEDAN, NEEDS, graduate internship programs, national directorate of employment etcetera aimed at assisting young school leavers to acquire necessary resources to enable them start their own businesses and thus be self-sustainable.

However, a cursory look at Nigeria indicates that the country lacks entrepreneurship ability or that government entrepreneurship oriented policies are not effective. Ugwu (2006) argues that most entrepreneurship related policies and programs in Nigeria fall short of appropriate development frameworks. This according to analysts is as a result and obvious neglect of entrepreneurship 
development programmes in the country. But evidences from the developed societies show a positive relationship between entrepreneurship development and self-sustainability.

It is on the strength of the foregoing that this paper is set to examine entrepreneurship as a means for self sustainability in the Nigerian economy. The paper is therefore structured into five sections viz; Section I: Introduction, Section II: Literature Review, Section III: Methodology, Section IV: Results and Discussions and Section V: Conclusion.

\section{LITERATURE REVIEW}

\section{The Concept of Entrepreneurship}

Entrepreneurship like every other concept in the social and management services have defiled any universally acceptable definition. Various scholars have offered diverse definitions based on their backgrounds, experiences and cultures. Binks and Vak (1990) defined entrepreneurship as "an unrehearsed combination of economic resources instigated by the uncertain prospect of temporary monopoly profit. Tijani- Alawiye (2004) defines entrepreneurs as adding to the stock of existing small, medium and big enterprises, nurture them to growth and sustain them, with a view to achieving broad socio-economic developmental goals. One of these goals is sustaining employment which is a key to self-sustainability.

In this wise, Bennell (2000) maintains that governments, Non-Governmental Organisations and international bodies seeking to improve youth livelihoods could best pursue their empowerment objective by tapping into the dynamism of young people and build on their strong spirit of risk through entrepreneurship development.

Shane (2003) described entrepreneurship as the act of being an entrepreneur. According to him, the word entrepreneur which is a French word means "one who undertakes innovations, finance and business acumen in an effort to transform innovations into economic goods". He further continued that the result of entrepreneurship may be a new organization or a part of revitalizing mature organization in response to perceived opportunity.

Entrepreneurship therefore assumes a societal leadership role of spearheading the society's allocation of scarce productive resources amongst competing needs.

Thus, entrepreneurship activities and innovative ingenuity in Nigeria have developed enterprises in the following areas. Agricultural/agro-allied activities where there are foodstuffs, restaurants, fast food vending etc. In the area of solid minerals, there are quarrying, germ stone cutting/polishing and crushing engineering. In the area of information and telecom business, there are manufacturing and repairs of GSM accessories and the printing and selling of Recharge cards. In hospitality and tourism business, there are hotels, accommodation, resorts centres, film and home video production; in oil and gas business, there are construction and maintenance of pipelines, drilling, refining bye products. In the area of environmental and waste management business, there is refuse collection/disposal, recyclement, and drainage/sewage construction job. In the area of financial banking services, there is banking, insurance and stock trading. In engineering and fabrication work, there are machines and tools fabrications. There is also the building and construction, where there are plan and design services and material sourcing (Agbeze, 2012).

From the above elaboration, it will be deduced that, entrepreneurship is the sole activity that brings productive resources together to create an output whose value is hoped to exceed the cost of all the productive resources. It then follows that, when the value of output indeed exceeds the cost of resources used, profit is made and wealth is created thereby enhancing the living standard of the people.

Given the benefits entrepreneurship creates for the society and the existing entrepreneurship base in Nigeria, the government in recent time has embarked upon certain programmes and policies aimed at encouraging entrepreneurship development in the country. 


\section{SELECTED POLICY PROGRAMMES AIMED AT ENTREPRENEURSHIP DEVELOPMENT IN NIGERIA.}

The reality of the importance of entrepreneurship to society socio- economic development has led various levels of government in Nigeria to institute measures aim at enhancing entrepreneurial activities. These programmes according to Ohuremi and Gbenda, (2011) and (Sansi, 2003) are categories into two:

1. Entrepreneurship development programmes and institutions and

2. Finance and micro programmes and institutions.

The first category comprise policies and programmes aimed at stimulating developing and enhancing the capacities of entrepreneurs, while the second category consists of measures aimed at providing stress- free credit facilities for entrepreneurs. They are further shown in the table below:

Table 1: Policy Programmes aimed at Entrepreneurship Development in Nigeria

\begin{tabular}{|c|c|c|c|}
\hline S/No & PROGRAMME & OBJECTIVE & REMARKS \\
\hline 1 & $\begin{array}{l}\text { Industrial } \\
\text { Development } \\
\text { Centre's (IDCS) }\end{array}$ & $\begin{array}{l}\text { Provision of extension services to } \\
\text { SMEs in project appraisal and training }\end{array}$ & $\begin{array}{l}\text { Lack of adequate } \\
\text { equipment and funding }\end{array}$ \\
\hline 2 & $\begin{array}{lr}\text { Small } & \text { scale } \\
\text { industries credit } & \text { cheme (SSICS) }\end{array}$ & $\begin{array}{l}\text { Set up to provide technical financial } \\
\text { support for the SMEs }\end{array}$ & $\begin{array}{l}\text { Inadequate manpower to } \\
\text { monitor advances leading } \\
\text { to repayment default }\end{array}$ \\
\hline 3 & $\begin{array}{l}\text { The Nigerian } \\
\text { industrial } \\
\text { development bank } \\
\text { (NIDB) }\end{array}$ & $\begin{array}{l}\text { Designed to provide medium / long } \\
\text { term loans for financing of industrial } \\
\text { activities }\end{array}$ & $\begin{array}{l}\text { Financial and } \\
\text { administrative constraints } \\
\text { and currently embroiled in } \\
\text { merge controversy. }\end{array}$ \\
\hline 4 & $\begin{array}{l}\text { The Nigerian bank } \\
\text { for commerce and } \\
\text { industry }\end{array}$ & $\begin{array}{l}\text { Set up to provide financial services to } \\
\text { indigenous business community and to } \\
\text { administer the SME } 1 \text { World Bank } \\
\text { Loan Scheme. }\end{array}$ & $\begin{array}{l}\text { The bank suffered } \\
\text { operational problems, } \\
\text { which resulted into a state } \\
\text { of insolvency }\end{array}$ \\
\hline 5 & $\begin{array}{l}\text { National directorates } \\
\text { of } \quad \text { employment } \\
(\mathrm{NDE})\end{array}$ & $\begin{array}{l}\text { Responsible for vocational skills } \\
\text { development and small scale } \\
\text { enterprises programmes designed to } \\
\text { combat unemployment }\end{array}$ & $\begin{array}{l}\text { Lack f commitment by the } \\
\begin{array}{l}\text { different tires } \\
\text { government } \text { of } \\
\text { operations. }\end{array} \text { to its } \\
\end{array}$ \\
\hline 6 & $\begin{array}{l}\text { National Economic } \\
\text { reconstruction fund } \\
\text { (NERFUN) }\end{array}$ & $\begin{array}{l}\text { Fill in the gap in any observed } \\
\text { inadequacies in the provision of } \\
\text { medium to long term financing to } \\
\text { small and medium scale industrial } \\
\text { enterprises }\end{array}$ & $\begin{array}{l}\text { Currently embroiled in } \\
\text { merger controversy. }\end{array}$ \\
\hline 7 & $\begin{array}{l}\text { Family economic } \\
\text { advancement } \\
\text { programme (FEAP) }\end{array}$ & $\begin{array}{l}\text { Established to provide micro facilities } \\
\text { for entrepreneurs. }\end{array}$ & $\begin{array}{l}\text { Discontinued due } \\
\text { change in government }\end{array}$ \\
\hline 8 & People’s Bank & $\begin{array}{l}\text { Designed to make banking service } \\
\text { more accessible and extend credit to the } \\
\text { poor. }\end{array}$ & $\begin{array}{l}\text { Discontinued due } \\
\text { change in government }\end{array}$ \\
\hline 9 & Community Bank & $\begin{array}{l}\text { Designed to make banking credit } \\
\text { accessible to the active poor. }\end{array}$ & $\begin{array}{lr}\text { Discontinued } & \text { and } \\
\text { substituted } & \text { with } \\
\text { Microfinance Banks } & \end{array}$ \\
\hline 10 & $\begin{array}{l}\text { Better Life } \\
\text { programmes/ family } \\
\text { support programme } \\
(\text { BLP/FSP) }\end{array}$ & $\begin{array}{l}\text { Aimed at sensitizing and providing } \\
\text { micro- credit facilities for women } \\
\text { entrepreneurs. }\end{array}$ & $\begin{array}{l}\text { Discontinued due } \\
\text { change in government }\end{array}$ \\
\hline
\end{tabular}




\begin{tabular}{|c|l|l|l|}
\hline 11 & $\begin{array}{l}\text { Small and medium } \\
\text { enterprises } \\
\text { development agency } \\
\text { of Nigeria } \\
\text { (SMEDAN) }\end{array}$ & $\begin{array}{l}\text { Established to Promote the } \\
\text { Development of the MSME sector of } \\
\text { the Nigerian Economy }\end{array}$ & $\begin{array}{l}\text { The impact is not felt at all } \\
\text { levels of societal strata. }\end{array}$ \\
\hline 12 & $\begin{array}{l}\text { Small and Medium } \\
\text { Enterprise equity } \\
\text { Investment Scheme }\end{array}$ & $\begin{array}{l}\text { To provide credit facilities for small } \\
\text { and medium entrepreneurs }\end{array}$ & $\begin{array}{l}\text { Lack of national spread in } \\
\text { implementation }\end{array}$ \\
\hline 13 & $\begin{array}{l}\text { Micro Finance } \\
\text { Banks }\end{array}$ & $\begin{array}{l}\text { Established to provide finance for the } \\
\text { active poor in the population }\end{array}$ & $\begin{array}{l}\text { Lack of national spread } \\
\text { and high interest rate. }\end{array}$ \\
\hline
\end{tabular}

On the whole, the aggregate goals of these policies and programmes include amongst others, stimulation of economic development, empowerment of the disadvantaged portion of the population, employment generation and invariably, poverty reduction etc.

The major strands emerge from the remarks about the policy programmes on the table: the first strand encapsulates programmes that are not effective in their roles designed for them. The programmes that fall in the first strand have fallen victim of any or a combination of the following: discontinuation as a result of change in government, merger of related programmes as in the case of the merger of National Economic Reconstruction Fund (NERFUND), and the Nigerian Bank for Commerce and Industry (NBCI) into Bank of industry (BOI), or outright replacement with new programmes. A clear example is found in the recent replacement of community banks with Microfinance Bank.

The second strand that emerges from the remarks comprises policy programmes that are not performing effectively. For example, Sanusi (2003) as quoted in Oluremi and Gbenda (2011), in his appraisal of some government initiations in the area of entrepreneurship development, contends that most of the programmes are not well designed or lack adequate recourses both human and material, for them to meet the desired needs.

\section{PECULIAR FACTORS AFFECTING ENTREPRENEURSHIP IN NIGERIA}

Entrepreneurship researchers such as Thoritom (1999): public policies, Dobbin and Dowd (1997): regulations and policies; Baumol (1990): and physical infrastructure; Agboli and Ukanegbu (2006) have identified various environmental factors whichaffect the operations of entrepreneurship which some have been tagged external factors, principal among the factors identified are influence of firms, influence of markets etc. These they classified and presented as perceptions of Nigerian entrepreneurs to infrastructure services.

Table 2: Perceptions of Nigerian Entrepreneurs to Infrastructure Services

\begin{tabular}{|c|l|c|}
\hline S/N & Infrastructure & Major problem \% \\
\hline 1 & Electricity & 92 \\
\hline 2 & Water & 85 \\
\hline 3 & Tarred roads & 79 \\
\hline 4 & Waste & 73 \\
\hline 5 & Telecommunication & 69 \\
\hline 6 & Security (police) & 66 \\
\hline 7 & Trucking services & 51 \\
\hline 8 & Postal service & 27 \\
\hline 9 & Air freight service & 12 \\
\hline
\end{tabular}

In a related development, the World Bank (2005), as part of its finding in a study on doing Business across the globe states that: 
* Business in poor countries faces much large regulatory burdens than those in rich countries. They fall 3 times the administrative cost and nearly twice with them bureaucratic procedures and delays associated with them and they have favor than half the protective's of property agents of rich countries.

* Heavy regulation and weak property rights exclude the poor from doing business. In poor countries $40 \%$ if the economy is informed. Women, young and low- skilled workers are hurt.

Idehen (2007, April 26), an industrialist contends that without doubt, the greatest challenge that our business and others in Nigeria are facing is inadequate infrastructure of course, a lot of people have explained how lack of infrastructure greatly affects business. But the truth remains that the relevant agencies of government have no idea how monstrous the problem is. In our transport division, we spend a lot of money whenever our vehicle travels to other parts of the country, because of the very bad state of the roads. Power supply is the worst. The money we spend on acquisition and maintenance of generators can start a business of its own and employ a lot of people.

\section{SOME EMPIRICAL EVIDENCES ON THE LINK BETWEEN UNEMPLOYMENT AND ENTREPRENEURSHIP}

That unemployment is linked to entrepreneurship dates back at least to Oxenfeldt (1943), who pointed out that individuals confronted with unemployment and low prospects for wage employment turn to self-employment as a viable alternative. This was an extension of Knight's view that individuals make a decision among three states - unemployment, self-employment and employment. The actual decision is shaped by the relative prices of these three activities but there was a clear prediction that entrepreneurship would be positively related to unemployment. However, as Storey (1991) documents, the empirical evidence linking unemployment and entrepreneurship is fraught with ambiguities. While some studies find that greater unemployment serves as a catalyst for start-up activity (Reynolds, Miller and Makai, 1995; Reynolds, Storey and Westhead, 1994; Hamilton, 1989; Highfield and Smiley, 1987, and Yamawaki, 1990; Evans and Leighton, 1989 and 1990), still others have found that unemployment reduces the amount of entrepreneurial activity (Audretsch and Fritsch, 1994; Audretsch, 1995).

On the other hand, why should an increased amount of entrepreneurial activity impact unemployment? One approach to address this question can be inferred from the literature on Gibrat's Law. Gibrat's Law asserts that firm growth is independent of size. Sutton (1997) interprets "Gibrat's Legacy", as "The probability that the next opportunity taken up by any particular active firm is proportional to the current size of the firm." An important implication of Gibrat's Law is that shifting employment from large to small enterprises should have no impact on total employment, since the expected growth rates of both types of firms are identical. Thus, a restructuring of the economy away from large enterprises and towards small ones should have no impact on the unemployment rate.

However, there is strong and systematic empirical evidence suggesting that, in fact, Gibrat's Law does not hold across a broad spectrum of firm sizes. Two comprehensive and exhaustive compilations (Sutton, 1997; and Caves, 1998) of studies relating firm size to growth have produced what Geroski (1995) terms as a stylized fact that smaller firms have higher growth rates than their larger counterparts. Beginning with the pioneering studies by Evans (1987a and 1987b) and Hall (1987), along with Dunne, Roberts, and Samuelson (1988 and 1989), a central finding of this literature is that firm growth is negatively related to firm size and age. These findings have been confirmed in virtually every subsequent study undertaken, despite differences in country, time period, industry, and methodology used.

Evans and Leighton (1990) found that unemployment is positively associated with greater propensity to start a new firm. Many other studies establish that greater unemployment serves as a catalyst for startup activity (Reynolds, Miller and Makai, 1995; Reynolds, Storey and Westhead, 1994). Anyadike, Emeh and Ukah (2012), researched on entrepreneurship development and employment generation in Nigeria: problems and prospects, they found out that the major problems of 
entrepreneurship in generating employment in Nigeria include inadequate working capital, low standard of education and inadequate training among others. In a similar research by Oladele, Akeke and Oladunjiye (2011) on entrepreneurship development; a panacea for unemployment reduction in Nigeria, using the Ordinary Least Squares econometrics technique. The empirical result shows that variations in industrial production are caused by unemployment rate.

From the review of available literature on the subject matter under context, it is very pertinent at this point in time for a study like this; hence it is most likely to create a positive impact on the entrepreneurial landscape of Nigeria.

\section{METHODOLOGY}

This study employed a survey design with the six (6) Geo-political Zones of Nigeria constituting the population of the study. A sample of 10 entrepreneurs from each geo-political zone which totaled 60 was taken. The sample was purposive in nature since the study focused on entrepreneurs that have been in existence for at least 5 years. The research used both primary and secondary sources of data but primary source data was the main data used for data analysis. The data were collected using a 5point Likert Scale questionnaire, administered to selected entrepreneurs across the six geo-political zones in Nigeria. The Chi- Square statistic with the aid of the statistical package for social science (SPSS) will be used for testing the hypothesis. In order to confirm the contributions of entrepreneurship to sustainability of the Nigerian citizenry, we had postulated the following hypothesis:

$\mathrm{Ho}_{1}$ : There is no significant relationship between entrepreneurship and self sustainability in Nigeria.

$\mathrm{Ha}_{1}$ : There is a significant relationship between entrepreneurship and self sustainability in Nigeria.

\section{RESULTS AND DISCUSSIONS}

Table 3: Responses as to the Relationship between Entrepreneurship and Self Sustainability in Nigeria

\begin{tabular}{|l|l|l|l|l|l|l|}
\hline & Assertions & SA & A & U & SD & DA \\
\hline 1 & $\begin{array}{l}\text { Your ability to cater for the basic things of life and even more } \\
\text { can be attributed to your involvement in entrepreneurial } \\
\text { activities. }\end{array}$ & 32 & 20 & 2 & 4 & 2 \\
\hline 2 & $\begin{array}{l}\text { Entrepreneurship provides owners with sufficient wage } \\
\text { employment }\end{array}$ & 15 & 37 & 1 & 2 & 5 \\
\hline 3 & $\begin{array}{l}\text { The educational level of owners can be attributed to their } \\
\text { involvement in entrepreneurial activities }\end{array}$ & 16 & 29 & 3 & 3 & 7 \\
\hline 4 & $\begin{array}{l}\text { Entrepreneurs in Nigeria can be considered to be above the } \\
\text { poverty line considering the high level of poverty in the } \\
\text { country }\end{array}$ & 23 & 28 & 3 & 4 \\
\hline
\end{tabular}

Source: Field Survey, 2016

Table 3 shows that, on the assertion of whether the ability of entrepreneurs to cater for the basic things can be attributed to their involvement in entrepreneurship, 32 respondents representing 53. 3 percent strongly agreed to this assertion, 20 respondents representing 33.3 percent also agreed to this assertion, 2 respondents representing 3.3 per cent were undecided on the issue, 4 respondents representing 6.7 strongly disagreed that their ability to cater for the basic things of life can be attributed to their involvement in entrepreneurship and 2 respondents representing 3. 3 percent disagreed on the issue.

On the issue on whether entrepreneurship provides owners with sufficient wage employment, 15 respondents representing 25 per cent of the total respondents strongly agreed to the assertion, 37 respondents representing 61.7 per cent also agreed to this assertion, 1 respondent representing 1.7 per 
cent was undecided on the issue, 2 respondents representing 3.3 per cent strongly disagreed that entrepreneurship provides owners with sufficient wage employment and 5 respondents representing 8.3 per cent disagreed to this assertion.

On the issue on whether the educational level of owners can be attributed to their involvement in entrepreneurial activities, 18 respondents representing 30 per cent of the total respondents strongly agreed to this assertion, 29 respondents representing 48.3 per cent agreed to this assertion, 3 respondents representing 5 per cent were undecided on the issue, 3 respondents representing 5 per cent of the respondents strongly disagreed that the educational level of owners can be attributed to their involvement in entrepreneurial activities and 7 respondents representing 11.7 per cent disagreed to this assertion.

On the issue on whether entrepreneurs in Nigeria can be considered to be above the poverty line considering the high level of poverty in the country, 23 respondents representing 38.3 per cent of the total respondents strongly agreed to this assertion, 28 respondents representing 46.7 per cent agreed to this assertion, 2 respondents representing 3.3 per cent were undecided on the issue, 3 respondents representing 5 percent of the respondents strongly disagreed that entrepreneurs in Nigeria can be considered to be above the poverty line and 4 respondents representing 6.7 per cent disagreed to this assertion.

The responses gotten above show that, majority of the respondents agree to the assertions raised which is a clear pointer to the fact that, entrepreneurship has the potentialities of ensuring self sustainability amongst the teeming Nigeria populace.

\section{Chi-Square Tests}

\begin{tabular}{|l|r|r|r|}
\hline & \multicolumn{1}{|c|}{ Value } & \multicolumn{1}{|c|}{ df } & $\begin{array}{r}\text { Asymp. Sig. (2- } \\
\text { sided) }\end{array}$ \\
\hline Pearson Chi-Square & $118.703^{\mathrm{a}}$ & 16 & .000 \\
Likelihood Ratio & 72.497 & 16 & .000 \\
Linear-by-Linear & 47.519 & 1 & .000 \\
Association & 60 & & \\
N of Valid Cases & & & \\
\hline
\end{tabular}

The chi- square test result shows a significant relationship between entrepreneurship and self sustainability (0.000). This further confirms the result gotten from responses of entrepreneurs that constituted the population of the study.

\section{CONCLUSION}

The state of the nation and the government are the crucial elements to the development of entrepreneurship of any country. The role of each differs widely on a global scale due to disparities in the local business environments. In a developing economy like ours where the poverty level is much high as a result of unemployment ratio, there is an urgent need to support the efforts of Nigerians to build an integrated and sustaining national economy. This will go a long way in integrating the economy into a globaleconomy and enhance industrial competitiveness that generates income and employment to eradicate poverty. Given the structural nature of our economy, which is overdependent on oil, poses a serious problem of fluctuations in the international oil market most likely to cause more harm if the concept of entrepreneurship is not seriously engaged in the other sectors of the economy. However the provision of basic infrastructures must be emphasized. 


\section{REFERENCES}

1. Agbeze, C. (2012) Entrepreneurship: The need to create wealth.... Why not now?.Ohafia Today. 2(32):7-12.s.

2. Agboli, M. and Ukaegbu, C. C. (2006). Business Environment and Entreprenuerial Activity in Nigeria: implications for Industrial Development. Journal of Modern African Studies, 44. 1: $1-30$

3. Baumol, W. (1990). 'Entrepreneurship: Productive, unproductive and destructive', Journal ofPolitical Economy, 98(5): 893-921.

4. Bennell, P. (2000). "Improving Youth Livelihoods in SSA: A review of policies and programs with particular emphasis on the link between sexual behavior and economic wellbeing" (draft). Report to IDRC.

5. Binks, M. \& Vale, P. (1990). Entrepreneurship and Economic Change. London: McGraw Hill.

6. Brundtland Commission (1987). Report of the World Commission on Environment and Development. United Nations.

7. Cave, R. (1998). Industrial Organization and New Finding on the Turnover and Mobility of Firms. Journal of Economic Literature. (36): 1947-1982.

8. Dobbin, F. and Dowd, T.J. (1997). How Policy Shapes Competition: Early Railroad Foundlings in Nassachusetts. Administrative science quarterly, 42: 501-29.

9. Dunne, T., Roberts, M.J. \& Samuelson, L.(1988), "Patterns of Firm Entry and Exit in U.S. Manufacturing Industries," Rand Journal of Economics, 104(4), 671-698.

10. Evans, D. S. (1987a), "The Relationship between Firm Growth, Size and Age: Estimates for 100 Manufacturing Industries," Journal of Industrial Economics, 35(2), 567-581.

11. Evans, D. S. (1987b), "Tests of Alternative Theories of Firm Growth," Journal of Political Economy, 95(4), 657-674.

12. Evans, D.s.\& Leighton, L. (1990). Small business formation by unemployed and employed workers. Small Business Economics, 2(4): 319-330.

13. Geroski P. A. (1995), What do we know about entry? International Journal of Industrial Organization, Vol. 13, No. 4, 421-440.

14. Idehen, M. (2008). Infrastructure is the Biggest Challenge to Business in Nigeria. The Punch, April 26. Retrieved from www. Punchontheweb.com

15. Kuratko, D.F. (2009). Introduction to Entrepreneurship. 8th ed. Australia: South-Western.

16. Oluremi, H.A. \&Gbenga, M.A. (2011). Environmental Factors and Entrepreneurship Development in Nigeria. Journal of Sustainable Development in Africa, 13(4).

17. Sanusi, J.O. (2003, June). Overview of Government Efforts in the Development of SMEs and the Emergence of Small and medium Industries Equity Investment scheme (SMIESIS). A paper presented at the National Summit on SMIESIS Organized by Banker's Committee and Lagos Chamber of Commerce and Industry (LCCI), Lagos, $10^{\text {th }}$.

18. Shane, D. (2003). A General Theory of Entrepreneurship: The Individual Opportunity Nexus. USA: Edward Elgar Publication.

19. Thornton, P.H. (1999). 'The Sociology of Entrepreneurship', Annual Review of Sociology, 25: $19-46$.

20. Tijani-Alawiye, B. (2004). Entrepreneurship Processes and Small Business Management, Industrial Science Centre, Owoyemi house, Abeokuta road Sango Otta, Ogun State, Nigeria.

21. Ugwu, S.C. (2006). Public Policy Analysis: Issues, Principles, Theory and Applications. Enugu: Cjiezugo.

22. World Bank (2005). Doing Business in 2005- Removing Obstacles to Growth. Retrieved from http//www. Doingbusiness.org/documents/doingbusiness2005, PDF. 
APPENDIX 1

\begin{tabular}{|ll|r|r|r|r|r|r|}
\hline & & \multicolumn{3}{|c|}{ SufficientWageEmployment } & Total \\
\hline & & $\begin{array}{c}\text { Strongly } \\
\text { Agree }\end{array}$ & Agree & Undecided & $\begin{array}{c}\text { Strongly } \\
\text { Disagree }\end{array}$ & Disagree & \\
& Strongly Agree & 15 & 17 & 0 & 0 & 0 & 32 \\
& & $100.0 \%$ & $45.9 \%$ & $0.0 \%$ & $0.0 \%$ & $0.0 \%$ & $53.3 \%$ \\
& Agree & 0 & 20 & 0 & 0 & 0 & 20 \\
Cater For & & $0.0 \%$ & $54.1 \%$ & $0.0 \%$ & $0.0 \%$ & $0.0 \%$ & $33.3 \%$ \\
Basic Needs & Undecided & 0 & 0 & 1 & 1 & 0 & 2 \\
& Strongly & $0.0 \%$ & $0.0 \%$ & $100.0 \%$ & $50.0 \%$ & $0.0 \%$ & $3.3 \%$ \\
& Disagree & 0 & 0 & 0 & 1 & 3 & 4 \\
& & $0.0 \%$ & $0.0 \%$ & $0.0 \%$ & $50.0 \%$ & $60.0 \%$ & $6.7 \%$ \\
& Disagree & 0 & 0 & 0 & 0 & 2 & 2 \\
Total & & $0.0 \%$ & $0.0 \%$ & $0.0 \%$ & $0.0 \%$ & $40.0 \%$ & $3.3 \%$ \\
& & 15 & 37 & 1 & 2 & 5 & 60 \\
& & $100.0 \%$ & $100.0 \%$ & $100.0 \%$ & $100.0 \%$ & $100.0 \%$ & $100.0 \%$ \\
\hline
\end{tabular}

Chi-Square Tests

\begin{tabular}{|l|r|r|r|}
\hline & \multicolumn{1}{|c|}{ Value } & \multicolumn{1}{c|}{ df } & \multicolumn{1}{|c|}{$\begin{array}{c}\text { Asymp. Sig. } \\
\text { (2-sided) }\end{array}$} \\
\hline Pearson Chi-Square & $118.703^{\mathrm{a}}$ & 16 & .000 \\
Likelihood Ratio & 72.497 & 16 & .000 \\
Linear-by-Linear & 47.519 & 1 & .000 \\
Association & 60 & & \\
N of Valid Cases & & \\
\hline
\end{tabular}

a. 21 cells $(84.0 \%)$ have expected count less than 5 . The minimum expected count is .03 .

Symmetric Measures

\begin{tabular}{|c|c|c|c|c|c|}
\hline & & Value & $\begin{array}{l}\text { Asymp. Std. } \\
\text { Error }^{\mathrm{a}}\end{array}$ & Approx. $\mathrm{T}^{\mathrm{b}}$ & $\begin{array}{c}\text { Approx. } \\
\text { Sig. }\end{array}$ \\
\hline $\begin{array}{l}\text { Interval by } \\
\text { Interval }\end{array}$ & Pearson's R & .897 & .027 & 15.494 & $.000^{\mathrm{c}}$ \\
\hline $\begin{array}{l}\text { Ordinal by } \\
\text { Ordinal } \\
\mathrm{N} \text { of Valid Cases }\end{array}$ & Spearman Correlation & $\begin{array}{r}.725 \\
60\end{array}$ & .063 & 8.006 & $.000^{\mathrm{c}}$ \\
\hline
\end{tabular}

a. Not assuming the null hypothesis.

b. Using the asymptotic standard error assuming the null hypothesis.

c. Based on normal approximation. 
IRA-International Journal of Management \& Social Sciences

\begin{tabular}{|ll|r|r|r|r|r|r||}
\hline & & \multicolumn{4}{|c|}{ Educational Level } & \multirow{2}{*}{ Total } \\
\cline { 3 - 6 } & & $\begin{array}{c}\text { Strongly } \\
\text { Agree }\end{array}$ & Agree & Undecided & $\begin{array}{c}\text { Strongly } \\
\text { Disagree }\end{array}$ & Disagree & \\
\hline & Strongly Agree & 18 & 14 & 0 & 0 & 0 & 32 \\
& & $100.0 \%$ & $48.3 \%$ & $0.0 \%$ & $0.0 \%$ & $0.0 \%$ & $53.3 \%$ \\
& Agree & 0 & 15 & 3 & 2 & 0 & 20 \\
Cater For & & $0.0 \%$ & $51.7 \%$ & $100.0 \%$ & $66.7 \%$ & $0.0 \%$ & $33.3 \%$ \\
Basic Needs & Undecided & 0 & 0 & 0 & 1 & 1 & 2 \\
& & $0.0 \%$ & $0.0 \%$ & $0.0 \%$ & $33.3 \%$ & $14.3 \%$ & $3.3 \%$ \\
& Strongly Disagree & 0 & 0 & 0 & 0 & 4 & 4 \\
& & $0.0 \%$ & $0.0 \%$ & $0.0 \%$ & $0.0 \%$ & $57.1 \%$ & $6.7 \%$ \\
& Disagree & 0 & 0 & 0 & 0 & 2 & 2 \\
Total & & $0.0 \%$ & $0.0 \%$ & $0.0 \%$ & $0.0 \%$ & $28.6 \%$ & $3.3 \%$ \\
& & 18 & 29 & 3 & 3 & 7 & 60 \\
& & $100.0 \%$ & $100.0 \%$ & $100.0 \%$ & $100.0 \%$ & $100.0 \%$ & $100.0 \%$ \\
\hline
\end{tabular}

Chi-Square Tests

\begin{tabular}{|l|r|r|r|}
\hline & \multicolumn{1}{|c|}{ Value } & df & $\begin{array}{c}\text { Asymp. Sig. (2- } \\
\text { sided) }\end{array}$ \\
\hline Pearson Chi-Square & $88.413^{\mathrm{a}}$ & 16 & .000 \\
Likelihood Ratio & 75.682 & 16 & .000 \\
Linear-by-Linear & 46.002 & 1 & .000 \\
Association & 60 & & \\
N of Valid Cases & & \\
\hline
\end{tabular}

a. 21 cells $(84.0 \%)$ have expected count less than 5 . The minimum expected count is 10 .

Symmetric Measures

\begin{tabular}{|ll|r|r|r|r|}
\hline & \multicolumn{1}{|c|}{ Value } & \multicolumn{1}{c|}{$\begin{array}{c}\text { Asymp. Std. } \\
\text { Error }^{\mathrm{a}}\end{array}$} & \multicolumn{1}{|c|}{ Approx. $\mathrm{T}^{\mathrm{b}}$} & Approx. Sig. \\
\hline Interval by Interval & Pearson's R & .883 & .028 & 14.327 & $.000^{\mathrm{c}}$ \\
Ordinal by Ordinal & Spearman Correlation & .788 & .049 & 9.744 & $.000^{\mathrm{c}}$ \\
N of Valid Cases & 60 & & & \\
\hline
\end{tabular}

a. Not assuming the null hypothesis.

b. Using the asymptotic standard error assuming the null hypothesis.

c. Based on normal approximation. 
CaterForBasicNeeds * AbovePovertyLine Cross tabulation

\begin{tabular}{|ll|r|r|r|r|r|r|}
\hline & & \multicolumn{4}{|c|}{ AbovePovertyLine } & \multirow{2}{*}{ Total } \\
\cline { 3 - 7 } & & $\begin{array}{c}\text { Strongly } \\
\text { Agree }\end{array}$ & Agree & Undecided & $\begin{array}{c}\text { Strongly } \\
\text { Disagree }\end{array}$ & Disagree & \\
& Strongly Agree & 23 & 9 & 0 & 0 & 0 & 32 \\
& & $100.0 \%$ & $32.1 \%$ & $0.0 \%$ & $0.0 \%$ & $0.0 \%$ & $53.3 \%$ \\
& Agree & 0 & 19 & 1 & 0 & 0 & 20 \\
Cater For & & $0.0 \%$ & $67.9 \%$ & $50.0 \%$ & $0.0 \%$ & $0.0 \%$ & $33.3 \%$ \\
Basic & Undecided & 0 & 0 & 1 & 1 & 0 & 2 \\
Needs & & $0.0 \%$ & $0.0 \%$ & $50.0 \%$ & $33.3 \%$ & $0.0 \%$ & $3.3 \%$ \\
& Strongly Disagree & 0 & 0 & 0 & 2 & 2 & 4 \\
& & $0.0 \%$ & $0.0 \%$ & $0.0 \%$ & $66.7 \%$ & $50.0 \%$ & $6.7 \%$ \\
& Disagree & 0 & 0 & 0 & 0 & 2 & 2 \\
Total & & $0.0 \%$ & $0.0 \%$ & $0.0 \%$ & $0.0 \%$ & $50.0 \%$ & $3.3 \%$ \\
& & 23 & 28 & 2 & 3 & 4 & 60 \\
& & $100.0 \%$ & $100.0 \%$ & $100.0 \%$ & $100.0 \%$ & $100.0 \%$ & $100.0 \%$ \\
\hline
\end{tabular}

Chi-Square Tests

\begin{tabular}{|l|r|r|r|}
\hline & \multicolumn{1}{|c|}{ Value } & \multicolumn{1}{|c|}{ df } & $\begin{array}{c}\text { Asymp. Sig. (2- } \\
\text { sided) }\end{array}$ \\
\hline Pearson Chi-Square & $118.728^{\mathrm{a}}$ & 16 & .000 \\
Likelihood Ratio & 85.748 & 16 & .000 \\
Linear-by-Linear & 50.756 & 1 & .000 \\
Association & 60 & & \\
N of Valid Cases & & & \\
\hline
\end{tabular}

a. 21 cells $(84.0 \%)$ have expected count less than 5 . The minimum expected count is .07 .

\section{Symmetric Measures}

\begin{tabular}{|ll|r|r|r|r|}
\hline & \multicolumn{1}{|c|}{ Value } & \multicolumn{1}{c|}{$\begin{array}{c}\text { Asymp. Std. } \\
\text { Error }^{\mathrm{a}}\end{array}$} & \multicolumn{1}{|c|}{ Approx. T } & Approx. Sig. \\
\hline Interval by Interval & Pearson's R & .928 & .021 & 18.897 & $.000^{\mathrm{c}}$ \\
Ordinal by Ordinal & Spearman Correlation & .831 & .051 & 11.382 & $.000^{\mathrm{c}}$ \\
N of Valid Cases & 60 & & & \\
\hline
\end{tabular}
a. Not assuming the null hypothesis.
b. Using the asymptotic standard error assuming the null hypothesis.
c. Based on normal approximation. 